\title{
Article \\ Linking Bi-Metal Distribution Patterns in Porous Carbon Nitride Fullerene to Its Catalytic Activity toward Gas Adsorption
}

\author{
Parisa Nematollahi * ${ }^{*}$ and Erik C. Neyts \\ Research Group Plasmant, NANO Lab Center of Excellence, Department of Chemistry, University of Antwerp, \\ 2610 Antwerp, Belgium; Erik.Neyts@uantwerpen.be \\ * Correspondence: parisa.nematollahi@uantwerpen.be; Tel.:+32-32-652-346
}

Citation: Nematollahi, P.; Neyts, E.C. Linking Bi-Metal Distribution

Patterns in Porous Carbon Nitride

Fullerene to Its Catalytic Activity

toward Gas Adsorption.

Nanomaterials 2021, 11, 1794. https://

doi.org/10.3390/nano11071794

Academic Editor: Francesc Viñes Solana

Received: 27 May 2021

Accepted: 7 July 2021

Published: 9 July 2021

Publisher's Note: MDPI stays neutral with regard to jurisdictional claims in published maps and institutional affiliations.

\begin{abstract}
Immobilization of two single transition metal (TM) atoms on a substrate host opens numerous possibilities for catalyst design. If the substrate contains more than one vacancy site, the combination of TMs along with their distribution patterns becomes a design parameter potentially complementary to the substrate itself and the bi-metal composition. By means of DFT calculations, we modeled three dissimilar bi-metal atoms ( $\mathrm{Ti}, \mathrm{Mn}$, and $\mathrm{Cu}$ ) doped into the six porphyrin-like cavities of porous $\mathrm{C}_{24} \mathrm{~N}_{24}$ fullerene, considering different bi-metal distribution patterns for each binary complex, viz. Tix $\mathrm{Cu}_{\mathrm{z}} @ \mathrm{C}_{24} \mathrm{~N}_{24}, \mathrm{Ti}_{\mathrm{x}} \mathrm{Mn}_{\mathrm{y}} @ \mathrm{C}_{24} \mathrm{~N}_{24}$, and $\mathrm{Mn}_{\mathrm{y}} \mathrm{Cu}_{\mathrm{z}} @ \mathrm{C}_{24} \mathrm{~N}_{24}$ (with $\mathrm{x}, \mathrm{y}, \mathrm{z}=0-6$ ). We elucidate whether controlling the distribution of bi-metal atoms into the $\mathrm{C}_{24} \mathrm{~N}_{24}$ cavities can alter their catalytic activity toward $\mathrm{CO}_{2}, \mathrm{NO}_{2}, \mathrm{H}_{2}$, and $\mathrm{N}_{2}$ gas capture. Interestingly, $\mathrm{Ti}_{2} \mathrm{Mn}_{4} @ \mathrm{C}_{24} \mathrm{~N}_{24}$ and $\mathrm{Ti}_{2} \mathrm{Cu}_{4} @ \mathrm{C}_{24} \mathrm{~N}_{24}$ complexes showed the highest activity and selectively toward gas capture. Our findings provide useful information for further design of novel few-atom carbon-nitride-based catalysts.
\end{abstract}

Keywords: $\mathrm{C}_{24} \mathrm{~N}_{24}$; porphyrin-like; porous fullerene; bi-metal doping; gas adsorption; nanocage

\section{Introduction}

Porous carbon-based catalysts are widely used as sorbents and support materials in heterogeneous catalysis [1-3]. The archetypical example is $\mathrm{C}_{60}$ fullerene, which has a closed-cage structure and can be synthesized with a highly defective surface and abundant holes $[4,5]$. It has high thermal stability, unique mechanical properties, high electronegativity, and high electron affinity [6]. Therefore, both pure and metal-doped $\mathrm{C}_{60}$ show promising applications in energy conversion $[7,8]$, fuel cells $[9,10]$, and for biomedical applications [11].

Recently, the adsorption and conversion of gas molecules on doped $\mathrm{C}_{60}$ fullerene by single transition metal (TM) or heteroatoms, especially nitrogen atoms, has gained significant interest $[12,13]$. Upon $\mathrm{N}$-doping, carbon $\pi$ electrons are activated by conjugating with the lone-pair electrons from $\mathrm{N}$. Thus, the $\mathrm{C}$ atoms neighboring $\mathrm{N}$ become active centers for catalytic reactions. For instance, Chen et al. [14] theoretically investigated the oxygen reduction reaction (ORR) mechanisms and catalytic abilities of pure and $\mathrm{N}$-doped fullerenes of various sizes $\left(\mathrm{C}_{20}, \mathrm{C}_{40}, \mathrm{C}_{60}\right.$, and $\left.\mathrm{C}_{180}\right)$. They found that the two pure and N-doped $\mathrm{C}_{20}$ and $\mathrm{C}_{180}$ structures are not active toward the adsorption of common intermediates produced during the ORR process. In contrast, $\mathrm{C}_{39} \mathrm{~N}$ showed the largest decrease in reaction energy of the rate-determining step in the relative energy profile, suggesting its ORR activity is the best among all the different sizes of fullerenes. Experimentally, $\mathrm{N}$-doped carbon materials are prepared using chemical vapor deposition (CVD) or reactive magnetron sputtering [15,16]. For example, Usachov et al. [17] synthesized a N-doped graphene nanosheet from s-triazine molecules. Recently, Zhai et al. [18] for the first time synthesized metal-free $\mathrm{N}$-doped graphene films on glass through plasma-assisted hot filament CVD using $\mathrm{N}_{2}$ gas as dopant. They found that both the hot filament and plasma 
source are essential for growing $\mathrm{N}$-doped graphene of high quality. By adjusting the $\mathrm{N}_{2}$ flow, the authors could easily modulate the $\mathrm{N}$ content, transmittance, and electrical properties of the graphene films.

The chemical inertness of pure fullerenes prevents their possible application for gas capture. Single metal doping $\left(\mathrm{M}-\mathrm{C}_{60}\right)$, like $\mathrm{C}_{58} \mathrm{Pt}$ and $\mathrm{C}_{59} \mathrm{Pt}$ [19], significantly modifies the electronic structure of $\mathrm{C}_{60}$, rendering it chemically active. However, one of the main challenges in the synthesis of $\mathrm{M}-\mathrm{C}_{60}$ is the often-observed aggregation of metal atoms $[8,20]$. Recently, extensive efforts have been put into developing single-site catalysts such as pyrolyzed TM-modified porphyrin complexes ( $\mathrm{TM}=\mathrm{Fe}, \mathrm{Co}, \mathrm{Mn}, \mathrm{Cr}, \mathrm{Ni}$ ) [21-31], which can be used in various applications like ORR and batteries [24,32-36]. The single TM atom doped in these porphyrin units was firmly fixed, preventing metal aggregation. Recently, the porphyrin-like porous $\mathrm{C}_{24} \mathrm{~N}_{24}$ has been of great interest as truncated $\mathrm{N}$-doped $\mathrm{C}_{60}$ nanocage. The $\mathrm{C}_{24} \mathrm{~N}_{24}$ fullerene has six $\mathrm{N}_{4}$ cavities with eight s-triazine rings, which are connected via $C-C$ bonds. Each porphyrin-like $\mathrm{N}_{4}$ cavity of $\mathrm{C}_{24} \mathrm{~N}_{24}$ can host a single TM atom. Recently, TM-doped $\mathrm{C}_{24} \mathrm{~N}_{24}$ and $\mathrm{C}_{24} \mathrm{~B}_{24}$ fullerenes were studied for hydrogen storage [37-39], ORR [40], and gas conversion [41].

In this work, we investigate the catalytic activity of bi-metal atom doping in $\mathrm{C}_{24} \mathrm{~N}_{24}$, using $\mathrm{Ti}, \mathrm{Mn}$, and $\mathrm{Cu}$ as metals. In particular, we here focus on the influence of the metal atom distribution in the catalytic activity of the modified structures. We carefully investigated the adsorption characteristics, electronic properties, and charge transfer properties of our novel catalysts. We found that varying the TM ratio indeed has an important effect on the properties and catalytic activities of the catalysts toward adsorption of gas species. Our calculations can provide the fundamental adsorption mechanism of such a novel material, supporting its possible exploitation to be applied as a green catalyst for gas detection.

\section{Computational Details}

All quantum chemical DFT computations are performed using the Gaussian16 package [42]. We first tested fourteen DFT functional/basis set combinations (including GGA, meta-GGA, and hybrid functionals) for geometry optimization (see Table S1 of Supplementary Materials). As can be seen in Table S1, the obtained $\mathrm{E}_{\mathrm{b}}$ values calculated with the B3LYP-D3/6-311G* are in close agreement with the reported $\mathrm{E}_{\mathrm{b}}$ for $\mathrm{H}_{2}(-4.52 \mathrm{eV})[43,44]$, formation energy $\left(\mathrm{E}_{\mathrm{f}}\right)$ of pristine $\mathrm{C}_{24} \mathrm{~N}_{24}(-7.40 \mathrm{eV})$, and $\mathrm{E}_{\mathrm{b}}$ of $\mathrm{Ti}_{6} @ \mathrm{C}_{24} \mathrm{~N}_{24}(-8.14 \mathrm{eV})$, as well as the geometry values for C-C (1.55 $\AA$ ) and C-N (1.34 $\AA$ ) bond length [45].

The cohesive energy (per atom) of $\mathrm{C}_{24} \mathrm{~N}_{24}$ is defined as:

$$
\mathrm{E}_{\mathrm{coh}}=(1 / 48)\left(\mathrm{E}_{\mathrm{C} 24 \mathrm{~N} 24}-24 \mathrm{E}_{\mathrm{C}}-24 \mathrm{E}_{\mathrm{N}}\right)
$$

where the $\mathrm{E}_{\mathrm{C} 24 \mathrm{~N} 24}, \mathrm{E}_{\mathrm{C}}$, and $\mathrm{E}_{\mathrm{N}}$ are the calculated total energy of the pure nanocage, carbon, and nitrogen atom, respectively. The $\mathrm{E}_{\mathrm{b}}$ of each doped TM in $\mathrm{C}_{24} \mathrm{~N}_{24}$ for a homogeneous TM-doped $\mathrm{C}_{24} \mathrm{~N}_{24}\left(\mathrm{TM}_{6} @ \mathrm{C}_{24} \mathrm{~N}_{24}\right)$ and with different metal ratios ( $\left.\mathrm{x}, \mathrm{y}, \mathrm{z}=0-6\right)$ was calculated using Equations (2) and (3), respectively:

$$
\mathrm{E}_{\mathrm{b}(\mathrm{TM} 6 @ \mathrm{C} 24 \mathrm{~N} 24)}=(1 / 6)\left(\mathrm{E}_{\mathrm{TM} 6 @ \mathrm{C} 24 \mathrm{~N} 24}-6 \mathrm{E}_{\mathrm{TM}}-\mathrm{E}_{\mathrm{C} 24 \mathrm{~N} 24}\right)
$$

$$
\mathrm{E}_{\mathrm{b}(\text { TixMnyCuz@C24N24) }}=(1 / 6)\left(\mathrm{E}_{\mathrm{TixMnyCuz}-\mathrm{C} 24 \mathrm{~N} 24}-\mathrm{E}_{\mathrm{C} 24 \mathrm{~N} 24}-\mathrm{xE}_{\mathrm{Ti}}-\mathrm{y} \mathrm{E}_{\mathrm{Mn}}-\mathrm{zE} \mathrm{Cu}_{\mathrm{Cu}}\right),(\mathrm{x}, \mathrm{y}, \mathrm{z}=0-6)
$$

where, in Equation (2), the $\mathrm{E}_{\mathrm{TM} 6 @ \mathrm{C} 24 \mathrm{~N} 24}$ and $\mathrm{E}_{\mathrm{TM}}$ refers to the total energy of one type TM-doped $\mathrm{C}_{24} \mathrm{~N}_{24}(\mathrm{Ti}, \mathrm{Mn}$, or $\mathrm{Cu}$ ) and the TM atom, respectively. In Equation (3), the $\mathrm{E}_{\text {TixMnyCuz@C24N24 }}$ is the total energy of the doped $\mathrm{C}_{24} \mathrm{~N}_{24}$ complex and $\mathrm{xE}_{\mathrm{Ti}}, \mathrm{yE} \mathrm{E}_{\mathrm{Mn}}$, and $\mathrm{zE}_{\mathrm{Cu}}$ are defined as the total energy of $\mathrm{Ti}, \mathrm{Mn}$, and $\mathrm{Cu}$ metal atoms times the number of doped $\mathrm{Ti}$ atoms (x), Mn atoms (y), and $\mathrm{Cu}$ atoms (z) into the six porphyrin cavities of $\mathrm{C}_{24} \mathrm{~N}_{24}$ nanocage, respectively.

The adsorption energy $\left(\mathrm{E}_{\mathrm{ads}}\right)$ of each gas moiety over the modified cage is defined as:

$$
\mathrm{E}_{\mathrm{ads}}=\mathrm{E}_{\mathrm{ads} @ \mathrm{TixMnyCuz}-\mathrm{C} 24 \mathrm{~N} 24}-\mathrm{E}_{\text {TixMnyCuz-C24N24 }}-\mathrm{E}_{\text {adsorbate }}
$$


where $\mathrm{E}_{\text {ads@TixMnyCuz-C24N24, }}, \mathrm{E}_{\text {TixMnyCuz-C24N24, and }} \mathrm{E}_{\text {adsorbate }}$ are the total energy of the adsorbate on the complex, pure complex, and the adsorbate molecule, respectively. The $\mathrm{x}$, $\mathrm{y}, \mathrm{z}$ values represent the number of each TM atom doped into the porphyrin-like $\mathrm{C}_{24} \mathrm{~N}_{24}$ cavities and are in the range of 0 to 6.

For each system, the zero-point energy $\left(\mathrm{E}_{\mathrm{ZPE}}\right)$ is calculated by summing vibrational frequencies over all (real) normal modes. Enthalpy and Gibbs energy changes are calculated at $298.15 \mathrm{~K}$ following the standard procedure outlined in the reference [46] To follow the nature of the adsorption process, the Wiberg bond indices (WBIs) were computed using NBO analysis. The WBIs are known as a better measure of bond strength relative to the overlap population, which is basis-set-dependent and often does not correlate well to bond strength. The WBIs are often similar in magnitude to the bond order expected from valence bond theory and have been used to propose trigger bonds in various energetic materials.

The WBI is a measure of the density between two atoms A and B. It determines by the sum of the off-diagonal square of the density matrix P (p\#q) [47]:

$$
\mathrm{WBI}_{\mathrm{AB}}=\sum_{\mathrm{P}^{\mathrm{A}}} \sum_{\mathrm{q}^{\mathrm{B}}} \mathrm{P}^{2} \mathrm{pq}
$$

\section{Results}

\subsection{Geometry of Pristine $C_{24} N_{24}$}

The porous $\mathrm{C}_{24} \mathrm{~N}_{24}$ is formed by first removing the $12 \mathrm{C}$ atoms in $\mathrm{C}_{60}$ that connect two pentagons, thus creating six di-vacancies, as shown with a red circle in Figure 1 , and subsequently substituting four undercoordinated C-atoms with $\mathrm{N}$-atoms, thus creating six porphyrin-like $\mathrm{N}_{4}$ cavities and eight connected s-triazine rings (see Figure 1 ). The calculated C-C and C-N bond lengths are $1.55 \AA$ and $1.34 \AA$, respectively. The calculated cohesive energy per atom in $\mathrm{C}_{24} \mathrm{~N}_{24}$ is $\mathrm{E}_{\text {coh }}=-7.81 \mathrm{eV}$, which is close to that reported by Ghosh et al. ( $-7.40 \mathrm{eV})$ [45] but significantly higher than the value of Tang et al. $(-5.78 \mathrm{eV})[38]$.

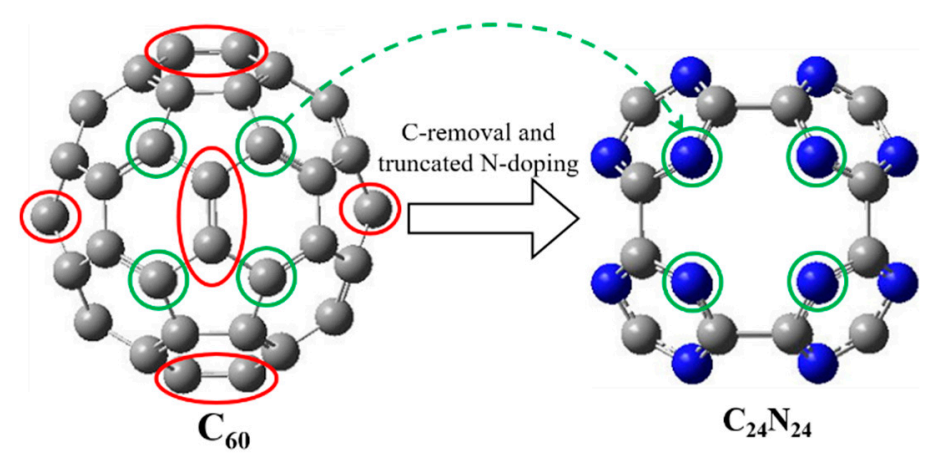

Figure 1. The optimized structure of porous $\mathrm{C}_{24} \mathrm{~N}_{24}$ originated from fullerene. Color code: $\mathrm{C}$, gray; $\mathrm{N}$, blue.

The HOMO-LUMO gap of $\mathrm{C}_{24} \mathrm{~N}_{24}$ is calculated to be to be $\mathrm{E}_{\mathrm{g}}=2.82 \mathrm{eV}$, which is similar to the value reported by Ma et al. [39] and Song et al. [48] and is higher than the value reported in other investigations $[40,45]$.

\subsection{Metal Distribution Patterns}

\subsubsection{Geometry and Electronic Properties of Bi-Metal Complexes}

The agglomeration of catalytically active TMs into clusters is a major challenge. This can be prevented by the strong interaction between TMs and support. $\mathrm{C}_{24} \mathrm{~N}_{24}$ fullerene possesses natural $\mathrm{N}_{4}$ rings that can host TM atoms (see Figure 1). We considered a combination of two metal atoms for the selected Ti, Mn, and Cu TMs with $3 d^{2} 4 s^{2}, 3 d^{5} 4 s^{2}$, and $3 \mathrm{~d}^{10} 4 \mathrm{~s}^{1}$ valence electrons, respectively, i.e., TiCu, TiMn, and $\mathrm{MnCu}$. Then, various distribution patterns of these dissimilar bi-metal atoms into the six porphyrin-like $\mathrm{C}_{24} \mathrm{~N}_{24}$ 
cavities were studied. Due to the presence of six cavities, the TM ratios will vary between zero to six. Therefore, we have $\mathrm{Ti}_{\mathrm{x}} \mathrm{Cu}_{\mathrm{z}}, \mathrm{Ti}_{\mathrm{x}} \mathrm{Mn}_{\mathrm{y}}$, and $\mathrm{Mn}_{\mathrm{y}} \mathrm{Cu}_{\mathrm{z}}$ doped $\mathrm{C}_{24} \mathrm{~N}_{24}$ fullerene $\left(\mathrm{Ti}_{\mathrm{x}} \mathrm{Cu}_{\mathrm{z}} @ \mathrm{C}_{24} \mathrm{~N}_{24}, \mathrm{Ti}_{\mathrm{x}} \mathrm{Mn}_{\mathrm{y}} @ \mathrm{C}_{24} \mathrm{~N}_{24}, \mathrm{Mn}_{\mathrm{y}} \mathrm{Cu}_{\mathrm{z}} @ \mathrm{C}_{24} \mathrm{~N}_{24}\right)$ with $\mathrm{x}, \mathrm{y}, \mathrm{z}=0-6$. Figure 2a-j shows a schematic presentation of possible bi-metal distribution patterns in the $\mathrm{N}_{4}$ cavities of $\mathrm{C}_{24} \mathrm{~N}_{24}$ cage. There are two main doping sites available in the $\mathrm{C}_{24} \mathrm{~N}_{24}$ cavities: equatorial and axial. As can be seen in Figure 2, equatorial and axial positions are placed in $\mathrm{x}, \mathrm{y}$ (red and black dashed lines), and $z$ (green dashed line) axis directions, respectively. Two metal atoms in a complex can be distributed into the $\mathrm{C}_{24} \mathrm{~N}_{24}$ cavities through seven different distribution patterns, as listed in Table 1.

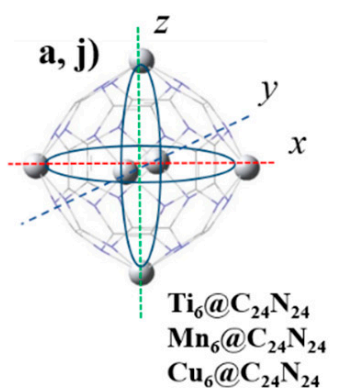

e)

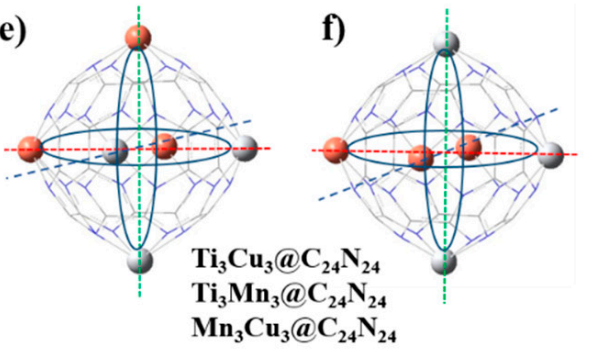

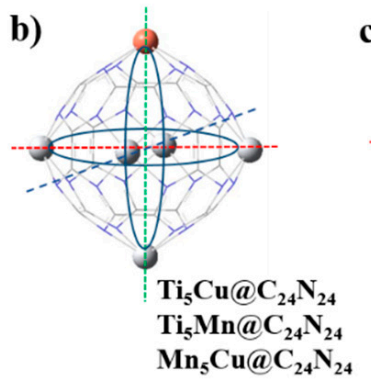

g)

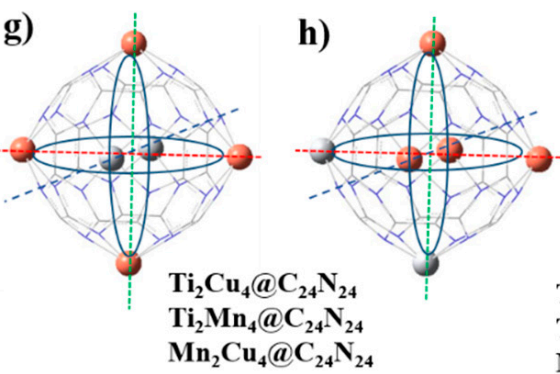

d)

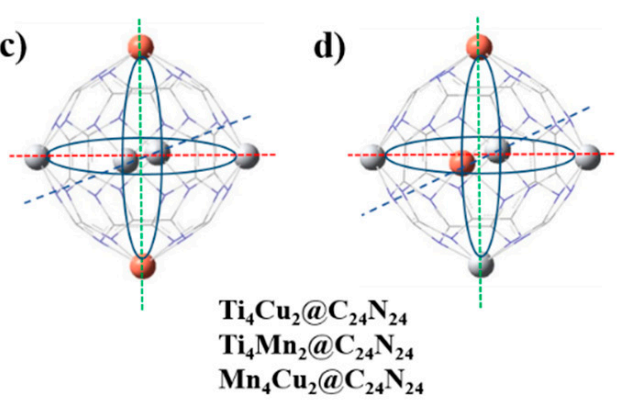

i)

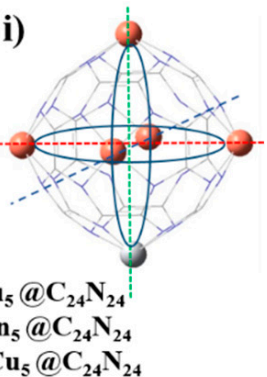

Figure 2. A schematic representative of possible distribution patterns of two dissimilar $\mathrm{TMs}\left(\mathrm{TM}_{1}: \mathrm{TM}_{2}\right)$ in $\mathrm{N}_{4}$-pyridinic cavities of the $\mathrm{C}_{24} \mathrm{~N}_{24}$ nanocage: (a) 6:0, (b) 5:1, (c,d) 4:2, (e,f) 3:3, (g,h) 2:4, (i) 1:5, (j) 0:6.Color code: white, Ti; orange, Cu.

Table 1. Distribution patterns of bi-metal atoms in $\mathrm{C}_{24} \mathrm{~N}_{24}$ cavities.

\begin{tabular}{ccccccccc}
\hline \multirow{2}{*}{ Complex/Metal-Ratio } & $\mathbf{6 : 0}$ & $\mathbf{5 : 1}$ & $\mathbf{4 : 2}$ & $\mathbf{3 : 3}$ & $\mathbf{2 : 4}$ & $\mathbf{1 : 5}$ & $\mathbf{0 : 6}$ \\
\cline { 2 - 8 } & $\mathbf{a}$ & $\mathbf{b}$ & $\mathbf{c}, \mathbf{d}$ & $\mathbf{e}, \mathbf{f}$ & $\mathbf{g}, \mathbf{h}$ & $\mathbf{i}$ & $\mathbf{j}$ \\
\hline $\mathrm{Ti}_{\mathrm{x}} \mathrm{Cu}_{\mathrm{z}} @ \mathrm{C}_{24} \mathrm{~N}_{24}$ & $\mathrm{Ti}_{6}$ & $\mathrm{Ti}_{5} \mathrm{Cu}$ & $\mathrm{Ti}_{4} \mathrm{Cu}_{2}$ & $\mathrm{Ti}_{3} \mathrm{Cu}_{3}$ & $\mathrm{Ti}_{2} \mathrm{Cu}_{4}$ & $\mathrm{TiCu}_{5}$ & $\mathrm{Cu}_{6}$ \\
\hline $\mathrm{Ti}_{\mathrm{x}} \mathrm{Mn}_{\mathrm{y}} @ \mathrm{C}_{24} \mathrm{~N}_{24}$ & $\mathrm{Ti}_{6}$ & $\mathrm{Ti}_{5} \mathrm{Mn}$ & $\mathrm{Ti}_{4} \mathrm{Mn}_{2}$ & $\mathrm{Ti}_{3} \mathrm{Mn}_{3}$ & $\mathrm{Ti}_{2} \mathrm{Mn}_{4}$ & $\mathrm{TiMn}_{5}$ & $\mathrm{Mn}_{6}$ \\
\hline $\mathrm{Mn}_{\mathrm{y}} \mathrm{Cu}_{\mathrm{z}} @ \mathrm{C}_{24} \mathrm{~N}_{24}$ & $\mathrm{Mn}_{6}$ & $\mathrm{Mn}_{5} \mathrm{Cu}$ & $\mathrm{Mn}_{4} \mathrm{Cu}_{2}$ & $\mathrm{Mn}_{3} \mathrm{Cu}_{3}$ & $\mathrm{Mn}_{2} \mathrm{Cu}_{4}$ & $\mathrm{MnCu}_{5}$ & $\mathrm{Cu}_{6}$ \\
\hline
\end{tabular}

\subsubsection{Binding Energy $\left(\mathrm{E}_{\mathrm{b}}\right)$}

To assess the stability of the modified complexes, the binding energy of each configuration was calculated (see Tables S2-S4). The computed $\mathrm{E}_{\mathrm{b}}$ for each complex changes in the range of $-3.55 \mathrm{eV}$ to $-8.11 \mathrm{eV}$. The lowest and highest $\mathrm{E}_{\mathrm{b}}$ values correspond

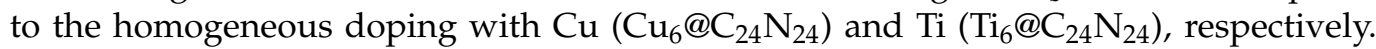
The calculated $\mathrm{E}_{\mathrm{b}}$ for $\mathrm{Ti}_{6} @ \mathrm{C}_{24} \mathrm{~N}_{24}$ is in good agreement with previous studies $(-8.61 \mathrm{eV}$ and $-8.14 \mathrm{eV}$ ) [39,45]. The binding energy of $\mathrm{Ti}_{\mathrm{x}} \mathrm{Cu}_{\mathrm{z}} @ \mathrm{C}_{24} \mathrm{~N}_{24}, \mathrm{Ti}_{\mathrm{x}} \mathrm{Mn}_{\mathrm{y}} @ \mathrm{C}_{24} \mathrm{~N}_{24}$, and $\mathrm{Mn}_{\mathrm{y}} \mathrm{Cu}_{\mathrm{z}} @ \mathrm{C}_{24} \mathrm{~N}_{24}(\mathrm{x}, \mathrm{y}, \mathrm{z}=0-6)$ configurations is plotted and compared in Figure 3.

The high $\mathrm{E}_{\mathrm{b}}$ values indicate a strong chemisorption of two dissimilar TMs at six $\mathrm{N}_{4}$ cavities of $\mathrm{C}_{24} \mathrm{~N}_{24}$, which inhibits the diffusion of TMs into the $\mathrm{C}_{24} \mathrm{~N}_{24}$ fullerene, increasing the stability of nanocages by metal doping. Due to the higher binding energy of $\mathrm{Ti}_{6} @ \mathrm{C}_{24} \mathrm{~N}_{24}$ and $\mathrm{Mn}_{6} @ \mathrm{C}_{24} \mathrm{~N}_{24}$ than the cohesive energy of bulk Ti (4.85 eV/atom) and Mn (2.92 eV/atom) [49], TM aggregation is not expected, and these materials are likely to be 
stable enough to be used in catalytic processes. In contrast, $\mathrm{Cu}_{6} @ \mathrm{C}_{24} \mathrm{~N}_{24}$ shows an $\mathrm{E}_{\mathrm{b}}$ of $-3.55 \mathrm{eV}$, slightly higher than the cohesive energy of bulk $\mathrm{Cu}$ (3.49 eV/atom) [50], such that homogeneously $\mathrm{Cu}$-doped $\mathrm{C}_{24} \mathrm{~N}_{24}$ is much less stable against TM agglomeration.

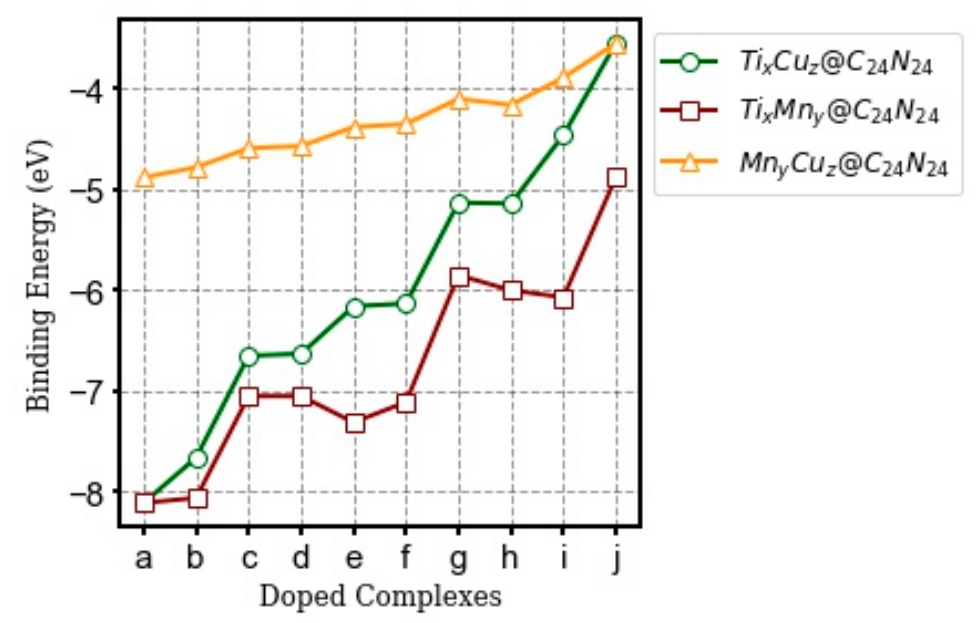

Figure 3. The calculated binding energy $\left(\mathrm{E}_{\mathrm{b}}\right)$ of $\mathrm{Ti}_{\mathrm{x}} \mathrm{Cu}_{\mathrm{z}} @ \mathrm{C}_{24} \mathrm{~N}_{24}, \mathrm{Ti}_{\mathrm{x}} \mathrm{Mn}_{\mathrm{y}} @ \mathrm{C}_{24} \mathrm{~N}_{24}$, and $\mathrm{Mn}_{\mathrm{y}} \mathrm{Cu}_{\mathrm{z}} @ \mathrm{C}_{24} \mathrm{~N}_{24}(\mathrm{x}, \mathrm{y}, \mathrm{z}=0-6)$. a-j refer to the bi-metal configurations with different metal ratios listed in Table 1 . All values are in $\mathrm{eV}$.

One can see from Figure 3 and Tables $\mathrm{S} 2-\mathrm{S} 4$ that by increasing the ratio of $\mathrm{Cu}$-to-Ti, $\mathrm{Mn}$-to-Ti, and Cu-to-Mn atoms in $\mathrm{Ti}_{\mathrm{x}} \mathrm{Cu}_{\mathrm{z}} @ \mathrm{C}_{24} \mathrm{~N}_{24}, \mathrm{Ti}_{\mathrm{x}} \mathrm{Mn}_{\mathrm{y}} @ \mathrm{C}_{24} \mathrm{~N}_{24}$, and $\mathrm{Mn}_{\mathrm{y}} \mathrm{Cu}_{\mathrm{z}} @ \mathrm{C}_{24} \mathrm{~N}_{24}$, the $\mathrm{E}_{\mathrm{b}}$ decreases (i.e., becomes less negative).

\subsubsection{NBO Charge Analysis}

Figure 4 shows the NBO charge accumulation on individual TMs in different configurations $(\mathrm{a}-\mathrm{j})$ for each complex. The precise values are reported in Tables S2-S4. Ti and $\mathrm{Cu}$ atoms in $\mathrm{Ti}_{\mathrm{x}} \mathrm{Cu}_{\mathrm{z}} @ \mathrm{C}_{24} \mathrm{~N}_{24}$ and $\mathrm{Mn}_{\mathrm{y}} \mathrm{Cu}_{\mathrm{z}} @ \mathrm{C}_{24} \mathrm{~N}_{24}$ complexes have the highest charge transfer values from the metal atom to the nanocage, in the range of 1.34 to $1.44 \mathrm{Iel}$ and 0.67 to $0.69 \mathrm{le}$ l, respectively. The high charge on the metal atoms corresponds to the high electron donation induced by the four surrounding $\mathrm{N}$ atoms in each porphyrin-like cavity where the $\mathrm{d}$ orbitals of $\mathrm{Ti}, \mathrm{Mn}$, and $\mathrm{Cu}$ atoms overlap with the neighboring nitrogen $\mathrm{sp}^{2}$ orbitals of the cavity to form a $\mathrm{sp}^{2} \mathrm{~d}$ hybridization. The charge transfer leads to the elongation of the average C-C bond $(\approx 1.55 \AA)$ compared to that of pristine $\mathrm{C}_{60}(1.45 \AA)$, indicating the activation of $\mathrm{C}_{24} \mathrm{~N}_{24}$ fullerene upon bi-metal doping.

\subsubsection{Thermodynamic Properties and Energy Gap $\left(E_{g}\right)$}

Figure 5 shows the changes in Gibbs free energy for each doped configuration, showing that bi-metallic doping is exothermic and exergonic at room temperature. The values are reported in Tables S2-S4.

Doping $\mathrm{C}_{24} \mathrm{~N}_{24}$ with various $\mathrm{Ti}, \mathrm{Mn}$, or $\mathrm{Cu}$ distributions significantly narrows the HOMO-LUMO gap of the $\mathrm{C}_{24} \mathrm{~N}_{24}$, leading to a noticeable energy gap $\left(\mathrm{E}_{\mathrm{g}}\right)$ reduction. The highest $\mathrm{E}_{\mathrm{g}}$ reduction occurs in $\mathrm{Ti}_{2} \mathrm{Mn}_{4} @ \mathrm{C}_{24} \mathrm{~N}_{24}$, where the calculated $\mathrm{E}_{\mathrm{g}}$ is reduced from $2.82 \mathrm{eV}$ in pure $\mathrm{C}_{24} \mathrm{~N}_{24}$ to $0.13 \mathrm{eV}$, making the complex act as a semi-conductor (see Figure 5b, complex g, purple line). The calculated HOMO-LUMO gap for doped configurations does not follow any particular order but in general is less than $<1.58 \mathrm{eV}$, and thus all configurations can be classified as semiconductors. Since the electrical conductivity is exponentially related to $E_{g}$, we expect that $\mathrm{Ti}_{2} \mathrm{Mn}_{4} @ \mathrm{C}_{24} \mathrm{~N}_{24}$ may show good electrical conductivity. 

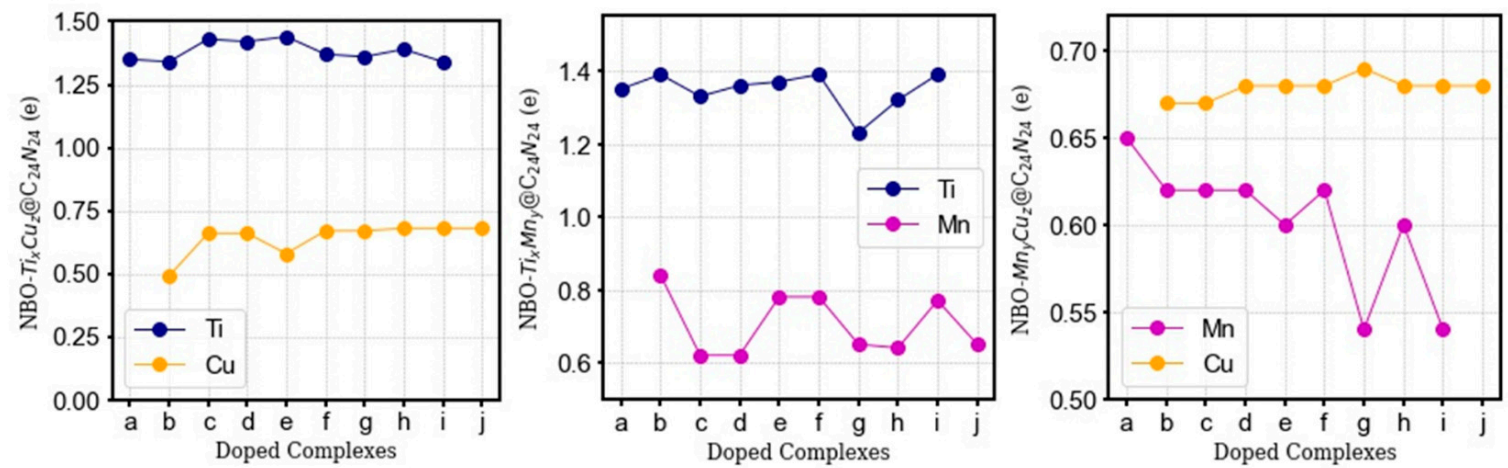

Figure 4. NBO charge analysis of individual Ti, $\mathrm{Mn}$, and $\mathrm{Cu}$ atoms in $\mathrm{Ti}_{\mathrm{x}} \mathrm{Cu}_{\mathrm{z}} @ \mathrm{C}_{24} \mathrm{~N}_{24}, \mathrm{Ti}_{\mathrm{x}} \mathrm{Mn}_{\mathrm{y}} @ \mathrm{C}_{24} \mathrm{~N}_{24}$, and $\mathrm{Mn}_{\mathrm{y}} \mathrm{Cu}_{\mathrm{z}} @$ $\mathrm{C}_{24} \mathrm{~N}_{24}$. The a-j complexes refer to the metal distribution patterns presented in Figure 2. All values are in $\mathrm{eV}$.

a)

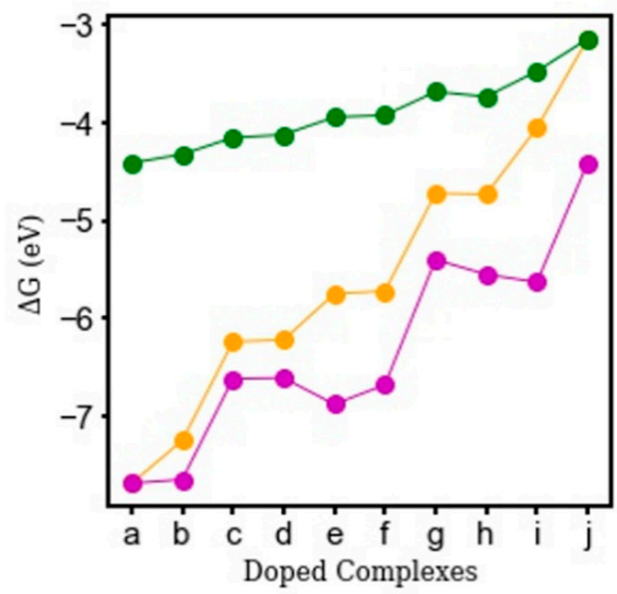

b)

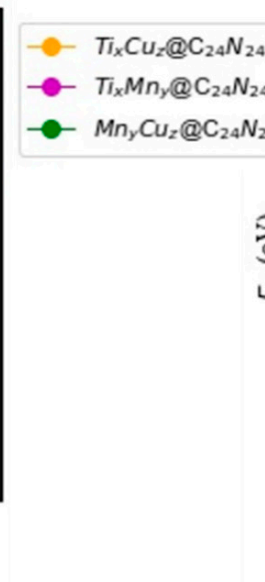

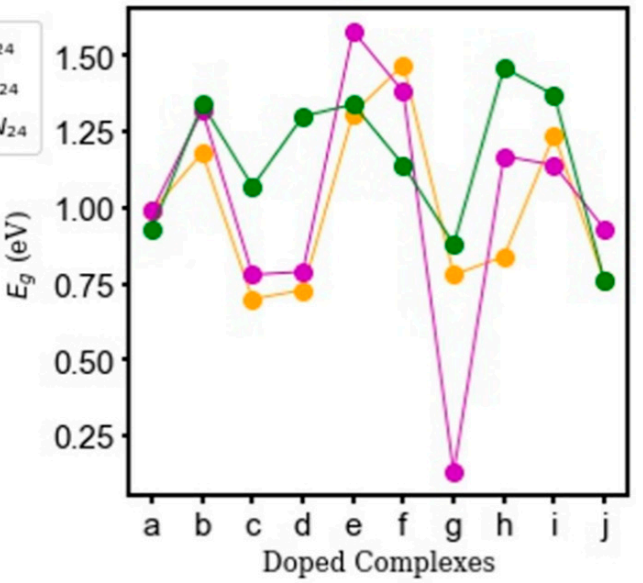

Figure 5. (a) The calculated changes in free energy $(\Delta \mathrm{G}$, at $298 \mathrm{~K}$ and $1 \mathrm{~atm})(\mathbf{b})$ and energy gap for $\mathrm{Ti}_{\mathrm{x}} \mathrm{Cu}_{\mathrm{z}} @ \mathrm{C}_{24} \mathrm{~N}_{24}$, $\mathrm{Ti}_{\mathrm{x}} \mathrm{Mn}_{\mathrm{y}} @ \mathrm{C}_{24} \mathrm{~N}_{24}$, and $\mathrm{Mn}_{\mathrm{y}} \mathrm{Cu}_{\mathrm{z}} @ \mathrm{C}_{24} \mathrm{~N}_{24}(\mathrm{x}, \mathrm{y}, \mathrm{z}=0-6)$. a-j refer to the bi-metal configurations with different metal ratios listed in Table 1.

Besides the effects of doping on the geometric, thermodynamic, and electronic properties of the complexes as described above, we find that the location of the second introduced $\mathrm{TM}$ atom in axial or equatorial positions has little effect. Therefore, we expect that the complexes $\mathrm{c}$ and $\mathrm{d}$, e and $\mathrm{f}$, and $\mathrm{g}$ and $\mathrm{h}$ exhibit similar catalytic activities.

\section{Catalytic Behavior of Bi-Metal Complexes toward Adsorption of Gas Species}

\subsection{Geometric Properties}

To explore the effect of bi-metal-doping on the catalytic behavior of each complex, we investigated the individual adsorption of four gas molecules $\left(\mathrm{CO}_{2}, \mathrm{NO}_{2}, \mathrm{H}_{2}\right.$, and $\left.\mathrm{N}_{2}\right)$ on each complex and their subgroup configurations. As shown in previous investigations, the existence of two dissimilar TM atoms in a catalyst induces various active sites [51-54]. Thus, it is important to first determine the available active sites in each substrate (see Figure S1). Considering each complex as a sphere, TM atoms are placed in $\mathrm{x}, \mathrm{y}$, and $\mathrm{z}$ directions. In homogeneous doping with one TM atom, one active site will be available (Figure S1a-j). By adding the second TM atom to the complex, it can be doped into one of the porphyrin vacancies along the $\mathrm{x}, \mathrm{y}$, or $\mathrm{z}$ direction, forming the complexes that are shown in Figure S1b. With two different TM atoms present in the complex, one would expect to have two different active sites available. However, for the adsorbent, there are not only two sites. We have labeled the TM atoms in Figure S1 (denoted as $i, j$, and $k$ ) to show different possible positions for the adsorbents to adsorb on the TM sites of each 
catalyst. It is clear that $i, k / j$ sites are located on the axial (perpendicular to the plane of the ring)/equatorial (in the plane of the ring) axis of the catalyst, respectively. Depending on the TM ratio, the adsorbent can adsorb on either $i, j$, or $k$ positions. One can see that for each configuration, two active sites are available except in configurations $b$ and $i$, in which, depending on the adsorption position of the adsorbent in the equatorial $(j)$ or axial ( $i$ and $k$ ) axis, three possible active sites are available. In addition, each adsorbent adopts mainly three adsorption modes on each active site of the substrates: parallel (side-on) or vertical (end-on) to the surface, and bridge positions.

Our results reveal that $\mathrm{CO}_{2}, \mathrm{H}_{2}$, and $\mathrm{N}_{2}$ adsorb strongly on $\mathrm{Ti}_{\mathrm{x}} \mathrm{Cu}_{\mathrm{z}} @ \mathrm{C}_{24} \mathrm{~N}_{24}$ and $\mathrm{Ti}_{\mathrm{x}} \mathrm{Mn}_{\mathrm{y}} @ \mathrm{C}_{24} \mathrm{~N}_{24}$ and weakly on $\mathrm{Mn}_{\mathrm{y}} \mathrm{Cu}_{\mathrm{z}} @ \mathrm{C}_{24} \mathrm{~N}_{24}$, while $\mathrm{NO}_{2}$ adsorbs quite strongly with $\left|\mathrm{E}_{\mathrm{ads}}\right|>6 \mathrm{eV}$ on all three complexes (see Figure 6 and Table S5). The adsorption behavior of each set of configurations is discussed below.

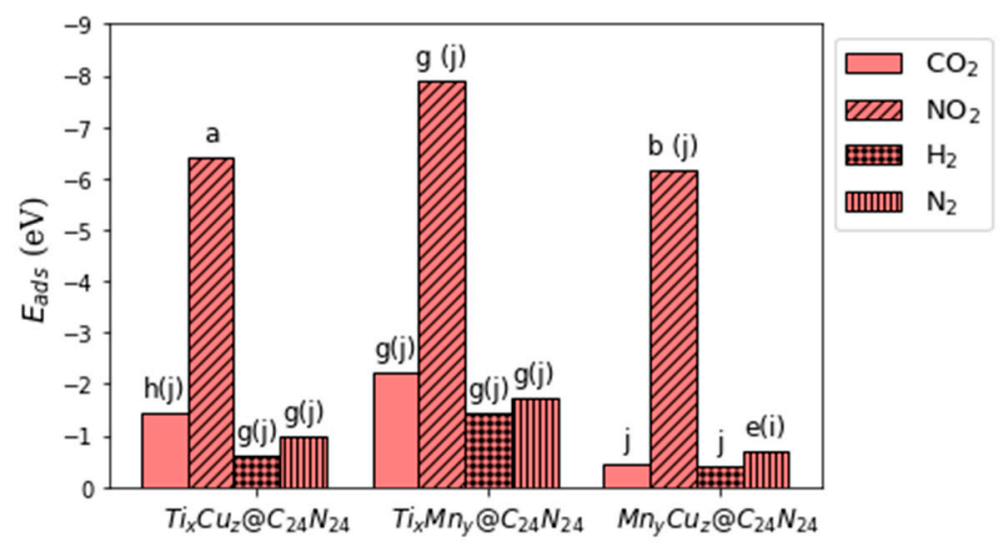

Figure 6. The more active bi-metal configurations of $\mathrm{Ti}_{\mathrm{x}} \mathrm{Cu}_{\mathrm{z}} @ \mathrm{C}_{24} \mathrm{~N}_{24}, \mathrm{Ti}_{\mathrm{x}} \mathrm{Mn}_{\mathrm{y}} @ \mathrm{C}_{24} \mathrm{~N}_{24}$, and $\mathrm{Mn}_{\mathrm{y}} \mathrm{Cu}_{\mathrm{z}} @ \mathrm{C}_{24} \mathrm{~N}_{24}(\mathrm{x}, \mathrm{y}, \mathrm{z}=0-6)$ toward $\mathrm{CO}_{2}, \mathrm{NO}_{2}, \mathrm{H}_{2}$, and $\mathrm{N}_{2}$ gas capture.

\subsection{Adsorption of $\mathrm{CO}_{2}$ and $\mathrm{H}_{2}$}

$\mathrm{Ti}_{2} \mathrm{Cu}_{4} @ \mathrm{C}_{24} \mathrm{~N}_{24}$ and $\mathrm{Ti}_{2} \mathrm{Mn}_{4} @ \mathrm{C}_{24} \mathrm{~N}_{24}$ tend to chemisorb $\mathrm{CO}_{2}$ and $\mathrm{H}_{2}$ species with high adsorption energies (see Figure 7). The covalent nature of the adsorbed species is confirmed by the calculated WBIs. As a result, the structure of $\mathrm{CO}_{2}$ is drastically distorted upon its adsorption on these complexes. It is bent over the Ti atom binding via its $\mathrm{C}$ and $\mathrm{O}$ and forms a triangular ring above the nanocage. The $\mathrm{O}-\mathrm{C}-\mathrm{O}$ angle is bent to $131.12^{\circ}$ in its adsorbed form and the $\mathrm{C}=\mathrm{O}$ bond length is elongated to $1.35 \AA$, which we attribute to the significant charge transfer of $0.49 \mathrm{lel}$ from the complex to the $2 \pi^{*}$ orbitals of the $\mathrm{CO}_{2}$ molecule. The obtained adsorption energies for $\mathrm{CO}_{2}$ are lower than those reported on $\mathrm{B}_{80}$ fullerene $(-3.49 \mathrm{eV})$ [55] and higher than those of N-S dual doped graphene $(-0.25 \mathrm{eV})$ [56] and Tidoped $\mathrm{C}_{2} \mathrm{~N}\left(\mathrm{E}_{\mathrm{ads}}=-0.95 \mathrm{eV}\right)$ [57]. The WBIs of both Ti-C and Ti-O bonds in $\mathrm{Ti}_{2} \mathrm{Cu}_{4} @ \mathrm{C}_{24} \mathrm{~N}_{24}$ and $\mathrm{Ti}_{2} \mathrm{Mn}_{4} @ \mathrm{C}_{24} \mathrm{~N}_{24}$ are 0.84 , confirming the covalent bond between $\mathrm{TM}$ and $\mathrm{CO}_{2}$ atoms and therefore its chemisorption over these substrates. $\mathrm{H}_{2}$ adsorbs dissociatively in a barrierless reaction, forming two covalent $\mathrm{Ti}-\mathrm{H}$ bonds above the $\mathrm{Ti}$ atom with $\mathrm{H}-\mathrm{H}$ bond length of $>2.0 \AA$ (see Figure 7). The NBO charge analysis (see Table S5) along with the calculated WBIs for both Ti-H bond lengths (0.89) confirms the covalent binding between $\mathrm{Ti}$ and $\mathrm{H}$ atoms and consequently the $\mathrm{H}_{2}$ chemisorption. Interestingly, we find that the adsorption energy of one hydrogen molecule on these complexes is higher than the adsorption of six $\mathrm{H}_{2}$ molecules on $\mathrm{Ti}_{6} @ \mathrm{C}_{24} \mathrm{~N}_{24}\left(\mathrm{E}_{\mathrm{ads}}=-0.48 \mathrm{eV}\right)$ [39] [39], Fe-B $38\left(\mathrm{E}_{\mathrm{ads}}=-0.42 \mathrm{eV}\right), \mathrm{Co}-\mathrm{B}_{38}$ $\left(\mathrm{E}_{\mathrm{ads}}=-0.72 \mathrm{eV}\right), \mathrm{Ni}-\mathrm{B}_{38}\left(\mathrm{E}_{\mathrm{ads}}=-0.89 \mathrm{eV}\right)[58]$, and $2 \mathrm{D}$ carbon allotrope $\Psi$ graphene $\left(\mathrm{E}_{\mathrm{ads}}=-0.34 \mathrm{eV}\right)$ [59]. 


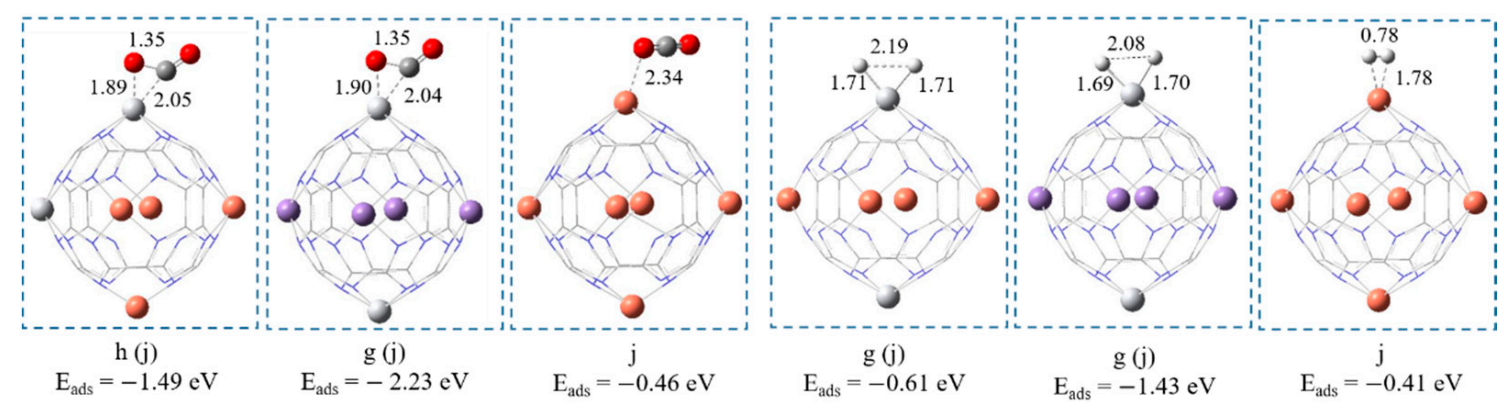

Figure 7. The optimized configurations of $\mathrm{CO}_{2}$ and $\mathrm{H}_{2}$ on bi-metal complexes. All bond distances are in $\AA$. Color code: white, Ti; orange, $\mathrm{Cu}$; purple, $\mathrm{Mn}$; red, $\mathrm{O}$; grey, $\mathrm{C}$; blue, $\mathrm{N}$.

Due to the lower activity of the $\mathrm{Cu}_{6} @ \mathrm{C}_{24} \mathrm{~N}_{24}$ complex, $\mathrm{CO}_{2}$ and $\mathrm{H}_{2}$ physisorb on this structure in their gas-phase form. The calculated $\mathrm{E}_{\mathrm{ads}}$ of $\mathrm{H}_{2}$ on $\mathrm{Cu}_{6} @ \mathrm{C}_{24} \mathrm{~N}_{24}$ is lower than that reported on $\mathrm{Ti}_{2} \mathrm{C}$ - and $\mathrm{Ti}_{2} \mathrm{CN}-\mathrm{Mxenes}\left(\mathrm{E}_{\mathrm{ads}}\right.$ in the range of -0.99 to $\left.-1.4 \mathrm{eV}\right)$ [60]. A negligible charge transfer from $\mathrm{CO}_{2}\left(\mathrm{H}_{2}\right)$ to $\mathrm{Cu}_{6} @ \mathrm{C}_{24} \mathrm{~N}_{24}$, the large $\mathrm{Cu}-\mathrm{C}(\mathrm{Cu}-\mathrm{H})$ bond length, and the low WBIs value of $0.12(0.2)$ confirm physisorption of these $\mathrm{CO}_{2}\left(\mathrm{H}_{2}\right)$ species on $\mathrm{Cu}_{6} @ \mathrm{C}_{24} \mathrm{~N}_{24}$.

\subsection{Adsorption of $\mathrm{N}_{2}$ and $\mathrm{NO}_{2}$}

Two different orientations were considered for $\mathrm{N}_{2}$ adsorption on each structure: sideon or end-on. The ideal catalyst would provide strong binding sites for the $\mathrm{N}_{2}$ molecule and thus weaken the $\mathrm{N}-\mathrm{N}$ bond. Our results indicate that the ideal orientation for $\mathrm{N}_{2}$ adsorption on $\mathrm{Ti}_{2} \mathrm{Cu}_{4} @ \mathrm{C}_{24} \mathrm{~N}_{24}$ and $\mathrm{Ti}_{2} \mathrm{Mn}_{4} @ \mathrm{C}_{24} \mathrm{~N}_{24}$ and $\mathrm{Mn}_{3} \mathrm{Cu}_{3} @ \mathrm{C}_{24} \mathrm{~N}_{24}$ is the end-on (see Figure 8). Upon $\mathrm{N}_{2}$ adsorption, the N-N bond length increases from $1.09 \AA$ in the gas phase to 1.11 and $1.12 \AA$ in its adsorbed form on $\mathrm{Ti}_{2} \mathrm{Cu}_{4} @ \mathrm{C}_{24} \mathrm{~N}_{24}$ and $\mathrm{Ti}_{2} \mathrm{Mn}_{4} @ \mathrm{C}_{24} \mathrm{~N}_{24}$ complexes, respectively. These values are in between the double and triple bond lengths, indicating the activation of $\mathrm{N}_{2}$ upon adsorption on Ti sites. The empty d orbitals of the Ti atom can accept the lone-pair electrons of $\mathrm{N}_{2}$. In turn, the Ti's capacity to donate electrons to the antibonding $\pi^{*}$ orbital of $\mathrm{N}_{2}$ is also significant for $\mathrm{N}_{2}$ binding to Ti. Therefore, this electron acceptance/donation process between the nanocage and $\mathrm{N}_{2}$ plays an important role in $\mathrm{N}_{2}$ activation (see Table S5). $\mathrm{Ti}_{2} \mathrm{Mn}_{4} @ \mathrm{C}_{24} \mathrm{~N}_{24}$ has a greater tendency for $\mathrm{N}_{2}$ activation with higher adsorption energy than that reported on Co-doped graphitic carbon nitride $(-1.63 \mathrm{eV})[61]$ and Fe doped phosphorene $(-0.81 \mathrm{eV})[62]$.
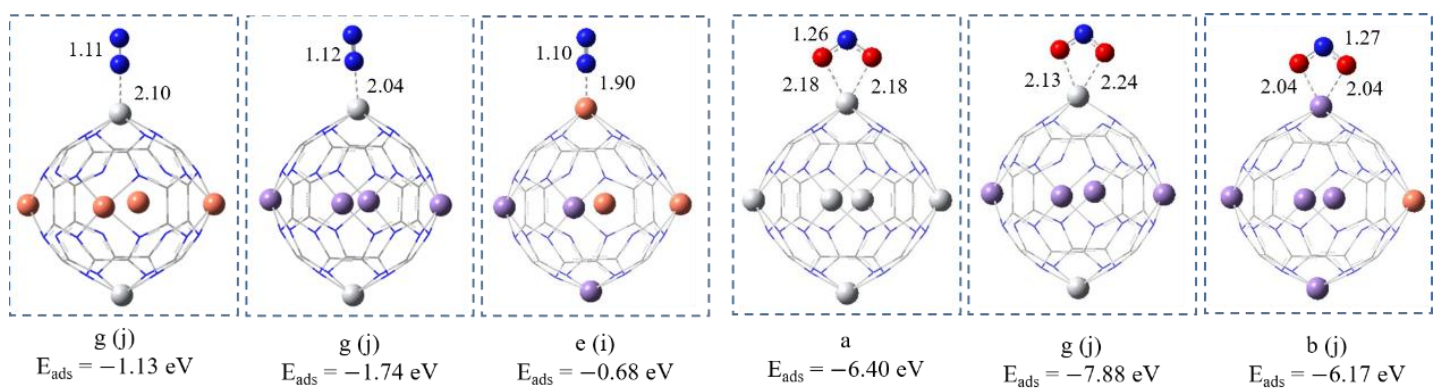

Figure 8. The optimized configurations of $\mathrm{N}_{2}$ and $\mathrm{N}_{2} \mathrm{O}$ on bi-metal complexes. All bond distances are in $\AA$. Color code: white, Ti; orange, $\mathrm{Cu}$; purple, $\mathrm{Mn}$; red, O; grey, $\mathrm{C}$; blue, N.

Although the $\mathrm{Mn}_{3} \mathrm{Cu}_{3} @ \mathrm{C}_{24} \mathrm{~N}_{24}$ complex adsorbs $\mathrm{N}_{2}$ molecule with lower $\mathrm{E}_{\mathrm{ads}}$, due to its lower catalytic activity toward gas adsorption, this value is still higher than that on $\mathrm{Mn}-\mathrm{Fe}$ bi-metal atoms anchored pyridinic nitrogen-doped graphene $\left(\mathrm{E}_{\mathrm{ads}}=-0.53 \mathrm{eV}\right)$ [63]. The calculated WBIs $(\approx 0.0001)$ and charge transfer confirm the $\mathrm{N}_{2}$ physisorption on $\mathrm{Mn}_{3} \mathrm{Cu}_{3} @ \mathrm{C}_{24} \mathrm{~N}_{24}$.

Regardless of all possible bi-metal distributions into the porphyrin $\mathrm{C}_{24} \mathrm{~N}_{24}$ cavities, the three $\mathrm{Ti}_{\mathrm{x}} \mathrm{Cu}_{\mathrm{z}} @ \mathrm{C}_{24} \mathrm{~N}_{24}, \mathrm{Ti}_{\mathrm{z}} \mathrm{Mn}_{\mathrm{y}} @ \mathrm{C}_{24} \mathrm{~N}_{24}$, and $\mathrm{Mn}_{\mathrm{y}} \mathrm{Cu}_{\mathrm{z}} @ \mathrm{C}_{24} \mathrm{~N}_{24}(\mathrm{x}, \mathrm{z}, \mathrm{y}=0-6)$ complexes with 
all the metal ratios exhibit an outstanding activity toward $\mathrm{NO}_{2}$ adsorption and activation. However, the more stable configurations are shown in Figure 8. One can see that the $\mathrm{NO}_{2}$ molecule binds via two $\mathrm{O}$ atoms with the Ti atom in $\mathrm{Ti}_{6} @ \mathrm{C}_{24} \mathrm{~N}_{24}$ and $\mathrm{Ti}_{2} \mathrm{Mn}_{4} @ \mathrm{C}_{24} \mathrm{~N}_{24}$ and with the $\mathrm{Mn}$ atom in the $\mathrm{Mn}_{5} \mathrm{Cu} @ \mathrm{C}_{24} \mathrm{~N}_{24}$ complex, respectively. Owing to the great NBO charge transfer from the nanocage to the $\mathrm{NO}_{2}$ molecule $(0.46 \mathrm{lel})$ reported in Table $\mathrm{S} 5$, the $\mathrm{N}$-O bond length increases compared to that of the gas phase (1.19 $\AA$ ).

\subsection{Electronic and Thermodynamic Properties}

To see if the adsorption of $\mathrm{CO}_{2}, \mathrm{NO}_{2}, \mathrm{H}_{2}$, and $\mathrm{N}_{2}$ gas species on the selected twelve more energetically stable complexes affects their electronic properties, we also investigated the LUMO-HOMO energy gap of each structure and compared our results with those of pristine bi-metal doped nanocages reported in Figure 5. The obtained $\mathrm{E}_{\mathrm{g}}$ values for adsorption structures are listed in Table S5, showing that $\mathrm{E}_{\mathrm{g}}$ indeed increases upon gas adsorption. This confirms the tunable electronic properties of $\mathrm{C}_{24} \mathrm{~N}_{24}$ nanocage induced by hosting six dissimilar bi-metals doping into its $\mathrm{N}_{4}$ cavities with various distribution patterns. All adsorption reactions are exothermic and exergonic, except for $\mathrm{H}_{2}$ adsorbed on the $\mathrm{Cu}_{6} @ \mathrm{C}_{24} \mathrm{~N}_{24}$ complex, which is slightly endergonic (see Table S5).

\subsection{Lifetime of the Adsorbed Gas Species on Bi-Metal Complexes}

The retention time of a molecule on a surface can be calculated with the Frenkel equation [64]:

$$
\tau=\tau_{0} e^{\frac{Q}{R T}}
$$

where $\tau_{0}$ is $10^{-12}$ to $10^{-13} \mathrm{~s}$ and $Q$ is the adsorption energy. We calculated the lifetime of each adsorbent over each configuration from which the energetically more favorable structures were chosen and plotted versus temperature. Figure 9 shows the computed lifetime vs. temperature for adsorbed $\mathrm{CO}_{2}, \mathrm{NO}_{2}, \mathrm{H}_{2}$, and $\mathrm{N}_{2}$ on the twelve nanocages discussed above. As can be seen in Figure 9, the lifetime of gas species on $\mathrm{Ti}_{\mathrm{x}} \mathrm{Cu}_{\mathrm{z}} @ \mathrm{C}_{24} \mathrm{~N}_{24}$ and $\mathrm{Ti}_{\mathrm{x}} \mathrm{Mn}_{\mathrm{y}} @ \mathrm{C}_{24} \mathrm{~N}_{24}$ at $400 \mathrm{~K}$ is higher than that on $\mathrm{Mn}_{\mathrm{y}} \mathrm{Cu}_{\mathrm{z}} @ \mathrm{C}_{24} \mathrm{~N}_{24}(\mathrm{x}, \mathrm{y}, \mathrm{z}=0-6)$, indicating that $\mathrm{Ti}_{\mathrm{x}} \mathrm{Cu}_{\mathrm{z}} @ \mathrm{C}_{24} \mathrm{~N}_{24}$ and $\mathrm{Ti}_{\mathrm{x}} \mathrm{Mn}_{\mathrm{y}} @ \mathrm{C}_{24} \mathrm{~N}_{24}$ are likely to be more efficient for gas capture. Obviously, increasing the temperature reduces the lifetime leading. However, $\mathrm{Ti}_{\mathrm{x}} \mathrm{Cu}_{\mathrm{z}} @ \mathrm{C}_{24} \mathrm{~N}_{24}$, $\mathrm{Ti}_{\mathrm{x}} \mathrm{Mn}_{\mathrm{y}} @ \mathrm{C}_{24} \mathrm{~N}_{24}$, and $\mathrm{Mn}_{\mathrm{y}} \mathrm{Cu}_{\mathrm{z}} @ \mathrm{C}_{24} \mathrm{~N}_{24}$ catalysts capture $\mathrm{NO}_{2}$ so actively that it will not desorb from the catalyst even at high temperatures. Therefore, we can conclude that, except for $\mathrm{NO}_{2}$, which effectively adsorbs and is retained on the catalysts, the gas species adsorb and remain on the Ti active site of $\mathrm{Ti}_{\mathrm{x}} \mathrm{Cu}_{\mathrm{z}} @ \mathrm{C}_{24} \mathrm{~N}_{24}$ and $\mathrm{Ti}_{\mathrm{x}} \mathrm{Mn}_{\mathrm{y}} @ \mathrm{C}_{24} \mathrm{~N}_{24}$ fullerene at room temperature, whereas they are not retained on $\mathrm{Mn}_{\mathrm{y}} \mathrm{Cu}_{\mathrm{z}} @ \mathrm{C}_{24} \mathrm{~N}_{24}$ sufficiently for gas capture.
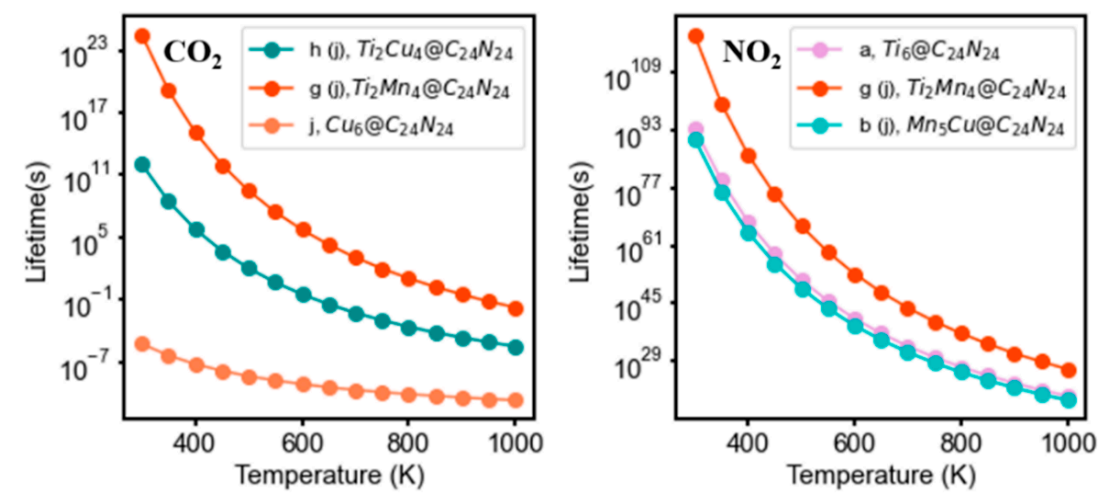

Figure 9. Cont. 

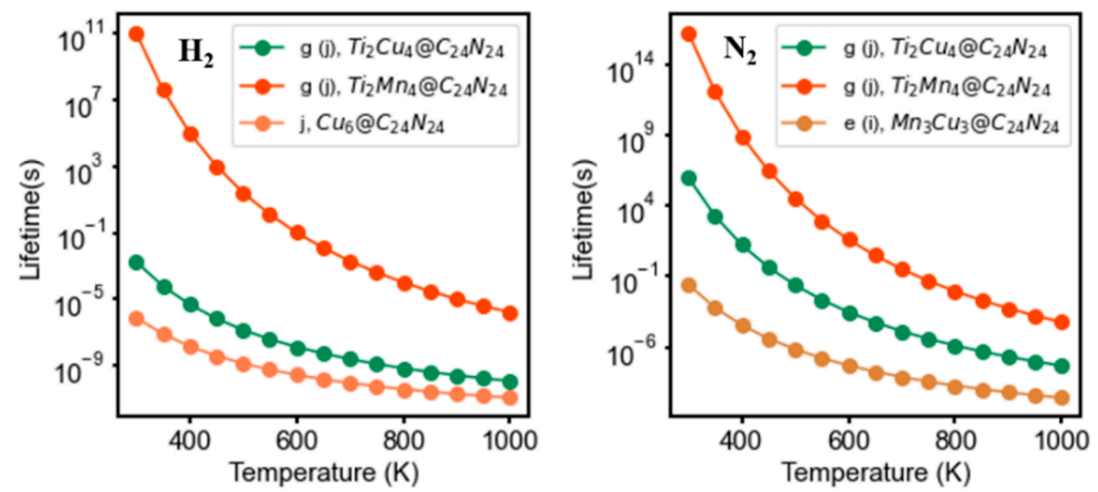

Figure 9. The calculated lifetime of the adsorbed gas species on $\mathrm{Ti}_{\mathrm{x}} \mathrm{Cu}_{\mathrm{z}} @ \mathrm{C}_{24} \mathrm{~N}_{24}, \mathrm{Ti}_{\mathrm{x}} \mathrm{Mn}_{\mathrm{y}} @ \mathrm{C}_{24} \mathrm{~N}_{24}$, and $\mathrm{Mn}_{\mathrm{y}} \mathrm{Cu}_{\mathrm{z}} @ \mathrm{C}_{24} \mathrm{~N}_{24}$.

\section{Conclusions}

In this work, the effect of dissimilar bi-metal doping into the six porphyrin-like cavities of a $\mathrm{C}_{24} \mathrm{~N}_{24}$ nanocage on the catalytic activity and adsorption characteristic of a number of greenhouse gases are investigated by means of DFT calculations. The binding energy and bulk cohesive energy calculations reveal that the selected TM atoms are stably trapped in the $\mathrm{C}_{24} \mathrm{~N}_{24}$ cavities, especially Ti/Cu atoms in $\mathrm{Ti}_{\mathrm{x}} \mathrm{Cu}_{\mathrm{z}} @ \mathrm{C}_{24} \mathrm{~N}_{24}$ and Ti/Mn atoms in $\mathrm{Ti}_{\mathrm{x}} \mathrm{Mn}_{\mathrm{y}} @ \mathrm{C}_{24} \mathrm{~N}_{24}(\mathrm{x}, \mathrm{y}, \mathrm{z}=0-6)$ complexes, suggesting the durability of the catalysts. Studying the adsorption behavior of these catalysts toward $\mathrm{H}_{2}, \mathrm{CO}_{2}, \mathrm{NO}_{2}$, and $\mathrm{N}_{2}$ sensing show that the $\mathrm{Ti}_{2} \mathrm{Mn}_{4} @ \mathrm{C}_{24} \mathrm{~N}_{24}$ is more active for adsorption of all species. Furthermore, the lifetime of each gas species on $\mathrm{Ti}_{\mathrm{x}} \mathrm{Cu}_{\mathrm{z}} @ \mathrm{C}_{24} \mathrm{~N}_{24}$ and $\mathrm{Ti}_{\mathrm{x}} \mathrm{Mn}_{\mathrm{y}} @ \mathrm{C}_{24} \mathrm{~N}_{24}$ at $400 \mathrm{~K}$ is higher than that on $\mathrm{Mn}_{\mathrm{y}} \mathrm{Cu}_{\mathrm{z}} @ \mathrm{C}_{24} \mathrm{~N}_{24}(\mathrm{x}, \mathrm{y}, \mathrm{z}=0-6)$, indicating that $\mathrm{Ti}_{\mathrm{x}} \mathrm{Mn}_{\mathrm{y}} @ \mathrm{C}_{24} \mathrm{~N}_{24}$ and $\mathrm{Ti}_{\mathrm{x}} \mathrm{Cu}_{\mathrm{z}} @ \mathrm{C}_{24} \mathrm{~N}_{24}$ are likely to be more efficient for gas capture. Overall, this work systematically provides the unique fundamental understanding of catalytic properties of two dissimilar bi-metal atom catalysts that could open a way for the future design and development of novel few-atom catalysts.

Supplementary Materials: The following are available online at https:/ / www.mdpi.com/article/10 $.3390 /$ nano11071794/s1, Figure S1: A schematic representative of available active sites (shown with red stars) on various $B M @ C_{24} \mathrm{~N}_{24}$ configurations.Color code: white, Ti; orange, $\mathrm{Cu}$., Table S1: The calculated cohesive energy (Ecoh) per atom of $\mathrm{C}_{24} \mathrm{~N}_{24}$, binding energy $\left(\mathrm{E}_{\mathrm{b}}\right.$ ) of hydrogen molecule and $\mathrm{Ti}_{6}$-doped $\mathrm{C}_{24} \mathrm{~N}_{24}$ along the energy gap of pristine $\mathrm{C}_{24} \mathrm{~N}_{24}$ using different functional and basis sets, Table S2: The calculated binding energy $\left(\mathrm{E}_{\mathrm{b}}\right)$, change of enthalpy $\left(\Delta \mathrm{H}_{298}\right)$, change of Gibbs free energy $\left(\Delta \mathrm{G}_{298}\right)$, energy gap $\left(\mathrm{E}_{\mathrm{g}}\right)$, and the average $\mathrm{NBO}$ charge on $\mathrm{Ti}_{\mathrm{x}} \mathrm{Cu}_{\mathrm{z}} @ \mathrm{C}_{24} \mathrm{~N}_{24}$. All the values are in eV, Table S3: The calculated binding energy $\left(\mathrm{E}_{\mathrm{b}}\right)$, change of enthalpy $\left(\Delta \mathrm{H}_{298}\right)$, change of Gibbs free energy $\left(\Delta \mathrm{G}_{298}\right)$, energy gap $\left(\mathrm{E}_{\mathrm{g}}\right)$, and the average $\mathrm{NBO}$ charge on $\mathrm{Ti}_{\mathrm{x}} \mathrm{Mn}_{\mathrm{y}} @ \mathrm{C}_{24} \mathrm{~N}_{24}$. All the values are in $\mathrm{eV}$, Table S4: The calculated binding energy $\left(\mathrm{E}_{\mathrm{b}}\right)$, change of enthalpy $\left(\Delta \mathrm{H}_{298}\right)$, change of Gibbs free energy $\left(\Delta \mathrm{G}_{298}\right)$, energy gap $\left(\mathrm{E}_{\mathrm{g}}\right)$, and the average NBO charge on $\mathrm{Mn}_{\mathrm{y}} \mathrm{Cu}_{\mathrm{z}} @ \mathrm{C}_{24} \mathrm{~N}_{24}$. All the values are in $\mathrm{eV}$, Table S5: The calculated total adsorption energy $\left(\mathrm{E}_{\text {ads }}\right)$, energy gap $\left(\mathrm{E}_{\mathrm{g}}\right)$, changes of enthalpy $\left(\Delta \mathrm{H}_{298}\right)$, changes of free energy $\left(\Delta \mathrm{G}_{298}\right)$, and NBO charge analysis for the energetically more stable adsorption configurations.

Author Contributions: Conceptualization, P.N.; methodology, P.N.; software, P.N.; validation, P.N.; formal analysis, P.N.; investigation, P.N.; resources, P.N.; data curation, P.N.; writing-original draft preparation, P.N.; writing-review and editing, P.N. and E.C.N.; visualization, P.N.; supervision, E.C.N.; project administration, P.N.; funding acquisition, E.C.N. and P.N. Both authors have read and agreed to the published version of the manuscript.

Funding: This research was funded by the Fund of Scientific Research Flanders (FWO), Belgium, Grant number $1261721 \mathrm{~N}$. The work was carried out in part using the Turing HPC infrastructure of the CalcUA core facility of the Universiteit Antwerpen, a division of the Flemish Supercomputer Centre VSC, funded by the Hercules Foundation, the Flemish Government (department EWI), and the University of Antwerp. 
Institutional Review Board Statement: Not applicable.

Informed Consent Statement: Not applicable.

Data Availability Statement: Not applicable.

Conflicts of Interest: The authors declare no conflict of interest.

\section{References}

1. Trogadas, P.; Fuller, T.F.; Strasser, P. Carbon as catalyst and support for electrochemical energy conversion. Carbon $2014,75,5-42$. [CrossRef]

2. Srinivasu, K.; Modak, B.; Ghosh, S.K. Porous graphitic carbon nitride: A possible metal-free photocatalyst for water splitting. J. Phys. Chem. C 2014, 118, 26479-26484. [CrossRef]

3. Albero, J.; Vidal, A.; Migani, A.; Concepción, P.; Blancafort, L.; García, H. Phosphorus-doped graphene as a metal-free material for thermochemical water reforming at unusually mild conditions. ACS Sustain. Chem. Eng. 2018, 7, 838-846. [CrossRef]

4. Pan, Y.; Liu, X.; Zhang, W.; Liu, Z.; Zeng, G.; Shao, B.; Liang, Q.; He, Q.; Yuan, X.; Huang, D.; et al. Advances in photocatalysis based on fullerene C60 and its derivatives: Properties, mechanism, synthesis, and applications. Appl. Catal. B Environ. 2020, 265, 118579. [CrossRef]

5. Han, F.; Wang, R.; Feng, Y.; Wang, S.; Liu, L.; Li, X.; Han, Y.; Chen, H. On demand synthesis of hollow fullerene nanostructures. Nat. Commun. 2019, 10, 1-9. [CrossRef]

6. Zettergren, H.; Alcami, M.; Martín, F. First- and second-electron affinities ofC60andC70isomers. Phys. Rev. A 2007, 76, 043205. [CrossRef]

7. Wu, Q.; Yang, L.; Wang, X.; Hu, Z. Carbon-based nanocages: A new platform for advanced energy storage and conversion. Adv. Mater. 2020, 32, e1904177. [CrossRef]

8. El Mahdy, A.M. Density functional investigation of CO and NO adsorption on TM-decorated C60 fullerene. Appl. Surf. Sci. 2016, 383, 353-366. [CrossRef]

9. Coro, J.; Suárez, M.; Silva, L.S.; Eguiluz, K.; Banda, G. Fullerene applications in fuel cells: A review. Int. J. Hydrogen Energy 2016, 41, 17944-17959. [CrossRef]

10. Wang, Y.; Jiao, M.; Song, W.; Wu, Z. Doped fullerene as a metal-free electrocatalyst for oxygen reduction reaction: A first-principles study. Carbon 2017, 114, 393-401. [CrossRef]

11. Cai, Q.; Hu, Z.; Zhang, Q.; Li, B.; Shen, Z. Fullerene (C60)/CdS nanocomposite with enhanced photocatalytic activity and stability. Appl. Surf. Sci. 2017, 403, 151-158. [CrossRef]

12. Sood, P.; Kim, K.C.; Jang, S.S. Electrochemical properties of boron-doped fullerene derivatives for lithium-ion battery ap-plications. ChemPhysChem 2018, 19, 753-758. [CrossRef] [PubMed]

13. Paraknowitsch, J.P.; Thomas, A. Doping carbons beyond nitrogen: An overview of advanced heteroatom doped carbons with boron, sulphur and phosphorus for energy applications. Energy Environ. Sci. 2013, 6, 2839-2855. [CrossRef]

14. Chen, X.; Chang, J.; Ke, Q. Probing the activity of pure and N-doped fullerenes towards oxygen reduction reaction by density functional theory. Carbon 2018, 126, 53-57. [CrossRef]

15. Hultman, L.; Stafström, S.; Czigány, Z.; Neidhardt, J.; Hellgren, N.; Brunell, I.F.; Suenaga, K.; Colliex, C. Cross-linked nano-onions of carbon nitride in the solid phase: Existence of a novel C 48 N 12 Aza-fullerene. Phys. Rev. Lett. 2001, 87, 225503. [CrossRef] [PubMed]

16. Otero, G.; Biddau, G.; Sanchez, C.S.; Caillard, R.; López, M.F.; Rogero, C.; Palomares, F.J.; Cabello, N.; Basanta, M.A.; Ortega, J.; et al. Fullerenes from aromatic precursors by surface-catalysed cyclodehydrogenation. Nat. Cell Biol. 2008, 454, 865-868. [CrossRef]

17. Usachov, D.; Vilkov, O.; Grüneis, A.; Haberer, D.; Fedorov, A.; Adamchuk, V.; Preobrajenski, A.B.; Dudin, P.; Barinov, A.; Oehzelt, M.; et al. Nitrogen-doped graphene: Efficient growth, structure, and electronic properties. Nano Lett. 2011, 11, 5401-5407. [CrossRef]

18. Zhai, Z.; Shen, H.; Chen, J.; Li, X.; Jiang, Y. Direct growth of nitrogen-doped graphene films on glass by plasma-assisted hot filament CVD for enhanced electricity generation. J. Mater. Chem. A 2019, 7, 12038-12049. [CrossRef]

19. Hayashi, A.; Xie, Y.; Poblet, J.M.; Campanera, J.M.; Lebrilla, C.B.; Balch, A.L. Mass spectrometric and computational studies of heterofullerenes ([C58Pt]-, [C59Pt]+) Obtained by laser ablation of electrochemically deposited films. J. Phys. Chem. A 2004, 108, 2192-2198. [CrossRef]

20. Gao, B.; Zhao, J.-X.; Cai, Q.-H.; Wang, X.-G.; Wang, X.-Z. Doping of calcium in C60Fullerene for enhancing CO2Capture and N2O transformation: A theoretical study. J. Phys. Chem. A 2011, 115, 9969-9976. [CrossRef]

21. He, T.; Santiago, A.R.P.; Du, A. Atomically embedded asymmetrical dual-metal dimers on N-doped graphene for ultra-efficient nitrogen reduction reaction. J. Catal. 2020, 388, 77-83. [CrossRef]

22. Guo, C.; Zhang, T.; Liang, X.; Deng, X.; Guo, W.; Wang, Z.; Lu, X.; Wu, C.-M.L. Single transition metal atoms on nitrogen-doped carbon for $\mathrm{CO}_{2}$ electrocatalytic reduction: $\mathrm{CO}$ production or further CO reduction? Appl. Surf. Sci. 2020, 533, 147466. [CrossRef]

23. Gao, X.; Zhou, Y.; Liu, S.; Cheng, Z.; Tan, Y.; Shen, Z. Single cobalt atom anchored on N-doped graphyne for boosting the overall water splitting. Appl. Surf. Sci. 2020, 502, 144155. [CrossRef]

24. Asset, T.; Atanassov, P. Iron-nitrogen-carbon catalysts for proton exchange membrane fuel cells. Joule 2020, 4, 33-44. [CrossRef] 
25. Nematollahi, P.; Neyts, E. Direct methane conversion to methanol on M and MN4 embedded graphene (M=Ni and Si): A comparative DFT study. Appl. Surf. Sci. 2019, 496, 143618. [CrossRef]

26. Liu, S.; Cheng, L.; Li, K.; Yin, C.; Tang, H.; Wang, Y.; Wu, Z. RuN4 doped graphene oxide, a highly efficient bifunctional catalyst for oxygen reduction and $\mathrm{CO}_{2}$ reduction from computational study. ACS Sustain. Chem. Eng. 2019, 7, 8136-8144. [CrossRef]

27. Holst-Olesen, K.; Silvioli, L.; Rossmeisl, J.; Arenz, M. Enhanced oxygen reduction reaction on Fe/N/C catalyst in acetate buffer electrolyte. ACS Catal. 2019, 9, 3082-3089. [CrossRef]

28. Jia, Y.; Xiong, X.; Wang, D.; Duan, X.; Sun, K.; Li, Y.; Zheng, L.; Lin, W.; Dong, M.; Zhang, G.; et al. Atomically dispersed Fe-N4 modified with precisely located $S$ for highly efficient oxygen reduction. Nano-Micro Lett. 2020, 12, 1-13. [CrossRef]

29. Chung, H.T.; Cullen, D.A.; Higgins, D.; Sneed, B.T.; Holby, E.F.; More, K.L.; Zelenay, P. Direct atomic-level insight into the active sites of a high-performance PGM-free ORR catalyst. Science 2017, 357, 479-484. [CrossRef]

30. Wan, X.; Liu, X.; Li, Y.; Yu, R.; Zheng, L.; Yan, W.; Wang, H.; Xu, M.; Shui, J. Fe-N-C electrocatalyst with dense active sites and efficient mass transport for high-performance proton exchange membrane fuel cells. Nat. Catal. 2019, 2, 259-268. [CrossRef]

31. Zitolo, A.; Ranjbar-Sahraie, N.; Mineva, T.; Emiliano, F.; Jia, Q.; Stamatin, S.; Harrington, G.F.; Lyth, S.M.; Krtil, P.; Mukerjee, S.; et al. Identification of catalytic sites in cobalt-nitrogen-carbon materials for the oxygen reduction reaction. Nat. Commun. 2017, 8, 1-11. [CrossRef] [PubMed]

32. Kattel, S.; Wang, G. A density functional theory study of oxygen reduction reaction on $\mathrm{Me}-\mathrm{N} 4(\mathrm{Me}=\mathrm{Fe}, \mathrm{Co}$, or Ni) clusters between graphitic pores. J. Mater. Chem. A 2013, 1. [CrossRef]

33. Kattel, S.; Atanassov, P.; Kiefer, B. Density functional theory study of Ni-Nx/C electrocatalyst for oxygen reduction in al-kaline and acidic media. J. Phys. Chem. C. 2012, 116, 17378-17383. [CrossRef]

34. Du, Z.; Chen, X.; Hu, W.; Chuang, C.; Xie, S.; Hu, A.; Yan, W.; Kong, X.; Wu, X.; Ji, H. Cobalt in nitrogen-doped graphene as single-atom catalyst for high-sulfur content lithium-sulfur batteries. J. Am. Chem. Soc. 2019, 141, 3977-3985. [CrossRef]

35. Bi, W.; Li, X.; You, R.; Chen, M.; Yuan, R.; Huang, W.; Wu, X.; Chu, W.; Wu, C.; Xie, Y. Surface immobilization of transition metal ions on nitrogen-doped graphene realizing high-efficient and selective $\mathrm{CO}_{2}$ reduction. Adv. Mater. 2018, 30, e1706617. [CrossRef]

36. Zhang, C.; Sha, J.; Fei, H.; Liu, M.; Yazdi, S.; Zhang, J.; Zhong, Q.; Zou, X.; Zhao, N.; Yu, H.; et al. Single-atomic ruthenium catalytic sites on nitrogen-doped graphene for oxygen reduction reaction in acidic medium. ACS Nano 2017, 11, 6930-6941. [CrossRef]

37. Guo, J.; Liu, Z.; Liu, S.; Zhao, X.; Huang, K. High-capacity hydrogen storage medium: Ti doped fullerene. Appl. Phys. Lett. 2011, 98, 023107. [CrossRef]

38. Tang, C.; Chen, S.; Zhu, W.; Kang, J.; He, X.; Zhang, Z. Transition metal Ti coated porous fullerene C24B24: Potential material for hydrogen storage. Int. J. Hydrogen Energy 2015, 40, 16271-16277. [CrossRef]

39. Ma, L.-J.; Hao, W.; Han, T.; Rong, Y.; Jia, J.; Wu, H.-S. Sc/Ti decorated novel C24N24 cage: Promising hydrogen storage materials. Int. J. Hydrogen Energy 2021, 46, 7390-7401. [CrossRef]

40. Modak, B.; Srinivasu, K.; Ghosh, S.K. Exploring metal decorated porphyrin-like porous fullerene as catalyst for oxygen re-duction reaction: A DFT study. Int. J. Hydrogen Energy 2017, 42, 2278-2287. [CrossRef]

41. Shakerzadeh, E.; Hamadi, H.; Esrafili, M.D. Computational mechanistic insights into CO oxidation reaction over Fe decorated C24N24 fullerene. Inorg. Chem. Commun. 2019, 106, 190-196. [CrossRef]

42. Ogliaro, F.; Bearpark, M.; Heyd, J.; Brothers, E.; Kudin, K.; Staroverov, V.; Keith, T.; Kobayashi, R.; Normand, J.; Raghavachari, K. Gaussian 16; Revision A. 03; Gaussian, Inc.: Wallingford, CT, USA, 2016.

43. Lide, D.R. CRC Handbook of Chemistry and Physics; CRC Press: Boca Raton, FL, USA, 2004.

44. De Lara-Castells, M.P.; Stoll, H.; Civalleri, B.; Causà, M.; Voloshina, E.; Mitrushchenkov, A.O.; Pi, M. Communication: A combined periodic density functional and incremental wave-function-based approach for the dispersion-accounting time-resolved dynamics of $4 \mathrm{He}$ nanodroplets on surfaces: 4He/graphene. J. Chem. Phys. 2014, 141, 151102. [CrossRef] [PubMed]

45. Srinivasu, K.; Ghosh, S.K. Transition metal decorated porphyrin-like porous fullerene: Promising materials for molecular hydrogen adsorption. J. Phys. Chem. C 2012, 116, 25184-25189. [CrossRef]

46. Ochterski, J.W. Thermochemistry in Gaussian; Gaussian Inc.: Wallingford, CT, USA, 2000.

47. Wiberg, K. Application of the pople-santry-segal CNDO method to the cyclopropylcarbinyl and cyclobutyl cation and to bicyclobutane. Tetrahedron 1968, 24, 1083-1096. [CrossRef]

48. Song, Y.-D.; Wang, L.; Wu, L.-M. How the alkali metal atoms affect electronic structure and the nonlinear optical properties of C24N24 nanocage. Optik 2017, 135, 139-152. [CrossRef]

49. Holcomb, D.; Kittel, C. Introduction to solid state physics. Am. J. Phys. 1967, 35. [CrossRef]

50. Philipsen, P.; Baerends, E. Cohesive energy of 3D transition metals: Density functional theory atomic and bulk calculations. Phys. Rev. B 1996, 54, 5326. [CrossRef]

51. Wei, Z.; He, J.; Yang, Y.; Xia, Z.; Feng, Y.; Ma, J. Fe, V-co-doped C2N for electrocatalytic N2-to-NH3 conversion. J. Energy Chem. 2021, 53, 303-308. [CrossRef]

52. Wang, Z.; Lee, H.; Chen, J.; Wu, M.; Leung, D.Y.; Grimes, C.A.; Lu, Z.; Xu, Z.; Feng, S.-P. Synergistic effects of Pd-Ag bimetals and g-C3N4 photocatalysts for selective and efficient conversion of gaseous $\mathrm{CO}_{2}$. J. Power Sources 2020, 466, 228306. [CrossRef]

53. Bian, Z.; Das, S.; Wai, M.H.; Hongmanorom, P.; Kawi, S. A review on bimetallic nickel-based catalysts for $\mathrm{CO}_{2}$ reforming of methane. ChemPhysChem 2017, 18, 3117-3134. [CrossRef] 
54. Wei, X.; Yang, X.-F.; Wang, A.-Q.; Li, L.; Liu, X.-Y.; Zhang, T.; Mou, C.-Y.; Li, J. Bimetallic Au-Pd alloy catalysts for N2O decomposition: Effects of surface structures on catalytic activity. J. Phys. Chem. C. 2012, 116, 6222-6232. [CrossRef]

55. Sun, Q.; Wang, M.; Li, Z.; Du, A.; Searles, D.J. Carbon dioxide capture and gas separation on B80Fullerene. J. Phys. Chem. C 2014, 118, 2170-2177. [CrossRef]

56. Li, J.; Hou, M.; Chen, Y.; Cen, W.; Chu, Y.; Yin, S. Enhanced $\mathrm{CO}_{2}$ capture on graphene via N, S dual-doping. Appl. Surf. Sci. 2017, 399, 420-425. [CrossRef]

57. Deshpande, S.S.; Deshpande, M.D.; Hussain, T.; Ahuja, R. Investigating $\mathrm{CO}_{2}$ storage properties of $\mathrm{C} 2 \mathrm{~N}$ monolayer functionalized with small metal clusters. J. $\mathrm{CO}_{2}$ Util. 2020, 35, 1-13. [CrossRef]

58. Liu, P.; Zhang, H.; Cheng, X.; Tang, Y. Transition metal atom Fe, Co, Ni decorated B38 fullerene: Potential material for hydrogen storage. Int. J. Hydrogen Energy 2017, 42, 15256-15261. [CrossRef]

59. Chakraborty, B.; Ray, P.; Garg, N.; Banerjee, S. High capacity reversible hydrogen storage in titanium doped 2D carbon allotrope I-graphene: Density Functional Theory investigations. Int. J. Hydrogen Energy 2021, 46, 4154-4167. [CrossRef]

60. Ding, B.; Ong, W.-J.; Jiang, J.; Chen, X.; Li, N. Uncovering the electrochemical mechanisms for hydrogen evolution reaction of heteroatom doped M2C MXene (M = Ti, Mo). Appl. Surf. Sci. 2020, 500, 143987. [CrossRef]

61. Wang, K.; Gu, G.; Hu, S.; Zhang, J.; Sun, X.; Wang, F.; Li, P.; Zhao, Y.; Fan, Z.; Zou, X. Molten salt assistant synthesis of three-dimensional cobalt doped graphitic carbon nitride for photocatalytic N2 fixation: Experiment and DFT simulation analysis. Chem. Eng. J. 2019, 368, 896-904. [CrossRef]

62. Wei, Z.; Zhang, Y.; Wang, S.; Wang, C.; Ma, J. Fe-doped phosphorene for the nitrogen reduction reaction. J. Mater. Chem. A 2018, 6, 13790-13796. [CrossRef]

63. Qu, M.; Qin, G.; Fan, J.; Du, A.; Sun, Q. Theoretical insights into the performance of single and double transition metal atoms doped on N-graphenes for N2 electroreduction. Appl. Surf. Sci. 2021, 537, 148012. [CrossRef]

64. DeBoer, J.H. The Dynamical Character of Adsorption. Soil Sci. 1953, 76, 166. [CrossRef] 